\title{
PENDEKATAN DINAMIS DALAM PENGEMBANGAN UKM DI KOTA TERNATE
}

\author{
Linda Umasugi \\ Staf Pengajar Faperta UMMU-Ternate,e-mail: linda.umasugi@yahoo.com
}

\begin{abstract}
ABSTRAK
Di dalam mewujudkan Visi pembangunan Dinas Koperasi dan UKM Kota Ternate adalah : "menjadi lembaga pemerintah yang kredibel dan efektif untuk mendinamisasikan pemberdayaan koperasi dan UMKM dalam rangka meningkatkan produktifitas, daya saing dan kemandirian". Untuk mewujudkannya maka perlu ditetapkan Misi Pembangunan Perindustrian dan Perdagangan sebagai berikut :1. Memberikan kontribusi nyata dalam pembangunan daerah melalui perumusan kebijakan;2. Mengkordinasikan perencanan, pelaksanaan dan pengendalian kebijakan pemberdayaan koperasi dan UMKM. Meningkatkan sinergi dan peran aktif masyarakat dan dunia usaha dalam rangka meningkatkan produktifitas, daya saing dan kemandirian koperasi dan UMKM secara sistematis dan berkelanjutan sampai dengan tahun 2009, jumlah tenaga kerja yang terserap dalam usaha kecil dari berbagai sektor ekonomi di Kota Ternate berjumlah 4.467 tenaga kerja atau 84,60\% dari total penyerapan tenaga kerja yang ada di Maluku Utara. Hal ini menunjukkan bahwa tingkat penyerapan tenaga kerja usaha kecil di Kota Ternate adalah cukup besar adalah terbesar jika dibandingkan dengan tingkat penyerapan tenaga kerja pada usaha non usaha besar dan menengah.

Di dalam implementasinya sendiri lebih ke strategi/program permodalan yaitu memberikan modal bagi usaha kecil dan menengah dengan kreteria pinjaman dari 5 juta-25 juta dan untuk pinjaman lebih dari itu maka pihak dari Dinas Koperasi dan UKM mengarahkannya ke pihak Perbankan. namun program yang belum terlaksana untuk lebih memajukan UKM di Kota Ternate adalah belum terwujudnya UKM trade center yang nantinya dipakai sebagai tempat pameran dan pemasaran dari hasil-hasil UKM itu sendiri. Program permodalan bagi usaha kecil dan menengah tersebut terlaksana karena adanya dana dari PEMDA Kota Ternate sekitar $1 \mathrm{M}$ lebih dan dana dari pemerintah pusat berupa dana Hibah untuk koperasi pemuda dan wanita serta dari lembaga penyaluran dana bergulir pada tahun 2008 untuk koperasi dan UKM.
\end{abstract}

Kata Kunci: UMKM, Produktifitas, Tenaga Kerja

\section{PENDAHULUAN}

\subsection{Latar Belakang}

Pembangunan nasional merupakan usaha peningkatan kualitas manusia dan masyarakat Indonesia yang dilakukan secara berkelanjutan, berlandaskan kemampuan Nasional dengan memanfaatkan kemajuan ilmu pengetahuan dan teknologi serta memperhatikan tantangan perkembangan global. Dalam pelaksanaanya mengacu pada kepribadian bangsa dan nilai luhur yang universal untuk mewujudkan kehidupan bangsa yang berdaulat, mandiri, berkeadilan, sejahtera, maju dan kukuh kekuatan moral dan etikanya.
Pembangunan yang hanya mengutamakan pertumbuhan ekonomi yang terpusat dan tidak merata serta tidak diimbangi kehidupan social, politik, ekonomi yang demokrasi dan berkeadilan telah menghasilkan fundamental pembangunan ekonomi yang rapuh. Rapuhnya pondasi perekonomian nasional telah mengakibatkan Indonesia terjebak dalam krisis ekonomi yang berkepanjangan serta menurunnya daya saing ekonomi nasional.

Konstitusi Republik Indonesia menegaskan salah satu tujuan pembangunan nasional adalah memajukan kesejahteraan umum, yang berarti kemakmuran masyarakatnya yang diutamkan, 
bukan kemakmuran orang seorang. Koperasi dan Usaha mikro, kecil dan menengah (UMKM) merupakan reperesentasi rakyat Indonesia dalam kehidupan ekonomi nasional sehingga perlu diberikan prioritas yag tinggi dalam pembangunan nasional. Untuk itu perlu disusun rencana pemberdayaan koperasi dan UMKM di Indonesia yang terintegrasi, sistimatis dan berkelanjutan.

Pancasila dan Undang-Undang Dasar 1945 merupakan landasan ideology dan konstitusional pembangunan nasional termasuk pemberdayaan koperasi dan usaha kecil dan menengah. Pemberdayaan koperasi dan usaha kecil dan menengah merupakan bagian integral dari pembangunan nasional untuk mewujudkan masyarakat Indonesia yang demokratis, adil dan makmur sesuai dengan amanat konstitusi Undang-Undang dasar Tahun 1945. Rencana strategi kementerian koperasi dan UKM ini disusun atas dasar landasan idiil pancasila dan landasan konstitusional Undang-Undang Dasar Tahun 1945, ketetapan MPR-RI, UndangUndang Nomor 25/1992 tentang perkoperasian, undang-undang nomor 9/1995 tentang usaha kecil, undang-undang nomor 25/2004 tentang system perencanaan pembangunan nasional, serta berbagai undang-undang,peraturan pemerintah, Inpres dan Kepres dan Perpres lainnya yang terkait.

\subsection{Permasalahan}

Dari uraian tersebut diatas maka dapat dirumuskan salah satu masalah yang dihadapi adalah belum maksimalnya pemberdayaan koperasi dan UKM di kota Ternate.

\subsection{Tujuan Penulisan}

Tujuan penulisan artikel adalah untuk membahas permasalahan yang dihadapi oleh koperasi dan UKM di kota ternate dan Memasimalkan pemberdayaan koperasi dan UKM di kota Ternate.

\section{Usaha Kecil Menengah}

Usaha Kecil dan Menengah disingkat UKM adalah sebuah istilah yang mengacu ke jenis usaha kecil yang memiliki kekayaan bersih paling banyak Rp 200.000.000 tidak termasuk tanah dan bangunan tempat usaha. Dan usaha yang berdiri sendiri. Menurut Keputusan Presiden RI no. 99 tahun 1998 pengertian Usaha Kecil adalah: "Kegiatan ekonomi rakyat yang berskala kecil dengan bidang usaha yang secara mayoritas merupakan kegiatan usaha kecil dan perlu dilindungi untuk mencegah dari persaingan usaha yang tidak sehat."

Kriteria usaha kecil menurut UU No. 9 tahun 1995 adalah sebagai berikut: 1. Memiliki kekayaan bersih paling banyak Rp. 200.000.000,(Dua Ratus Juta Rupiah) tidak termasuk tanah dan bangunan tempat usaha 2. Memiliki hasil penjualan tahunan paling banyak Rp. 1.000.000.000,- (Satu Miliar Rupiah) 3. Milik Warga Negara Indonesia 4. Berdiri sendiri, bukan merupakan anak perusahaan atau cabang perusahaan yang tidak dimiliki, dikuasai, atau berafiliasi baik langsung maupun tidak langsung dengan Usaha Menengah atau Usaha Besar 5. Berbentuk usaha orang perorangan, badan usaha yang tidak berbadan hukum, atau badan usaha yang berbadan hukum, termasuk koperasi. Di Indonesia, jumlah UKM hingga 2005 mencapai 42,4 juta unit lebih.

\subsection{Hubungan antara pertumbuhan ekonomi dan tingkat kemiskinan. \\ Pertumbuhan ekonomi dapat menurunkan} tingkat kemiskinan dengan menciptakan lapangan pekerjaan dan pertumbuhan jumlah pekerja yang cepat dan merata. Pertumbuhan ekonomi juga harus disertai dengan program pembangunan sosial.

\subsection{Pertumbuhan ekonomi dan tingkat pemerataan}

- Deininger and Squire $(1995,1996)$ dan Barro (1999): tidak ada relasi yang sistematis antara pertumbuhan pendapatan dan pola distribusinya

- Papanek (1977): tidak ada hubungan yang signifikan antara tingkat ketimpangan distribusi pendapatan dan tingkat pembangunan

- Goudie dan Ladd (1999): tidak ada hubungan yang jelas antara pertumbuhan ekonomi dengan kemerataan .

- Simon Kuznets: relasi antara kesenjangan pendapatan dan tingkat pendapatan per kapita berbentuk U terbalik

- Tambunan (2005); ada korelasi positif antara laju pertumbuhan dan tingkat kesenjangan ekonomi Indonesia pada dekade tahun 1970an dan 1980an

- Hill (1996): pada Pelita I tidak terjadi trickle down effect. Akibatnya, sampai tahun 1980-an laju pertumbuhan ekonomi Indonesia (PDB) relatif tinggi, tapi tingkat kesenjangan semakin meningkat. 


\subsection{Upaya peningkatan UKM}

\subsubsection{Internal}

- Implementasi manajemen usaha sederhana untuk UMKM

- Mempertahankan kepuasan dan menjaga hubungan baik dengan konsumen

- Meningkatkan dan mempertahankan kualitas produk

- Melakukan diversifikasi dan inovasi produk

- Membina hubungan baik dengan pihak yang berhubungan dengan operasional usaha, seperti pemasok dan distributor

- Meningkatkan keterampilan dan kapasitas tenaga kerja

- Ulet dan disiplin dalam menjalankan usaha

- Aktif mengikuti even promosi

2.3.2. Eksternal

- Menciptakan kondisi ekonomi yang kondusif bagi perkembangan UKM

- Pemanfaatan layanan Pusat Pelayanan dan Pengembangan UKM (P3 UKM)

- Pemanfaatan fasilitas Center for Development of Small and Medium Enterprises (CD-SMEs)

- Melakukan review terhadap kebijakan yang berdampak pada sektor ekonomi

- Membuka peluang investasi bagi pihak swasta

- Membuat kebijakan yang mendorong partisipasi lembaga keuangan untuk memberikan pinjaman usaha

- Peningkatan peran asosiasi sebagai mediator bagi pengusaha dan pemerintah

- Membentuk business centre (seperti yang diterapkan di Kab. Jembrana

\subsection{Peran pemerintah daerah dalam} meningkatkan keunggulan UKM

- Memperkuat klaster industri

- Membangun business centre

- Menyederhanakan birokrasi

- Menjadikan pengusaha UMKM sebagai mitra, bukan sebagai objek yang dikenai pungutan

- Mengidentifikasi kemungkinan dibukanya peluang investasi swasta.

- Memberikan stimulus bagi lembaga keuangan agar termotivasi untuk memberikan kredit bagi UMKM

- Membuat lembaga penjamin untuk memfasilitasi UMKM yang tidak cukup memiliki agunan dalam melakukan kredit

\subsection{Kelemahan UMKM dari segi manajemen}

- Mengabaikan Laporan Keuangan @Kurang memperhatikan SDM

- Belum Komputerize
- Mengandalkan sedikit Sumber Daya

- Kurang improvisasi dalam pemasaran

- Yang penting Harga Murah

- Kurang penghargaan terhadap konsumen

- Konsep Bersyukur yang salah kaprah (Segini saja cukup)

- Minimnya Anggaran

- Tidak Ada legalitas Usaha

\subsection{Ketentuan UMKM yang Dijamin}

- Usaha yg layak dan sudah berjalan selama dua tahun

- UMKM berupa Badan Usaha Perorangan, CV, Fa yg berbadan hukum PT / Koperasi

- Identitas pemilik dan legalitas usaha

- Tidak sedang menerima pembiayaan / KUR dari bank

- Kredit usaha mikro: $50-100$ juta

- Kredit usaha kecil: 100 - 250 juta

- Kredit usaha menengah/koperasi: 250 - 500 juta

- Kredit Kelompok/Gabungan: 2,5 M-5 M

\subsection{Manajemen Koperasi Dan UKM}

\subsubsection{Koperasi Syariah}

- Perkembangan LKS sejak tahun 1990

- Keyakinan akan sistem bunga sama dengan riba

- Belum maksimalnya fungsi sistem perbankan yang bersentuhan langsung dengan bisnis UMKM

- Adanya PP No. 9 tahun 1995 pasal 23 tentang koperasi yang menerapkan sistem imbalan margin dan bagi hasil.

\subsubsection{Ketentuan Dasar Koperasi Syariah}

- Menerakan sistem profit sharing baik untuk simpanan maupun pembiayaan anggota

- Menanggung risiko secara bersamasama baik pihak koperasi maupun anggota/peminjam dana yang usahanya mengalami kerugian.

\subsubsection{Modal Koperasi Syariah}

- Modal sendiri

- Simpanan Pokok - Simpanan Wajib Dana Cadangan atau Hibah

- Modal Pinjaman

- Modal Penyertaan

\subsubsection{Jenis Produk}

- Pembiayaan dengan sistem bagi hasil

- Skim Mudharabah - Skim Musyarakah

- Pembiayaan dengan Sistem Jual Beli 
- Murabahah - Al Bay' Bitshama Ajil (BBA) - Pinjaman Kebajikan (Qordul Hasan)

Keterbatasan :

- Belum ada payung undang-undang yang baku / standar

- Permodalan Terbatas

- Belum memiliki lembaga penjamin likuiditas spt perbankan

- Sistem teknologi informasi yang terbatas.

- Masih minimnya pengetahuan SDM tentang prinsip-prinsip operasional secara syariah.

Keunggulan :

- Lebih adil dengan prinsip syariah.

- Proses lebih cepat.

- Tingkat bagi hasil di atas rata-rata bank umum.

- Sektor mikro menjadi target utama, di mana mayoritas masyarakat Indonesia umumnya bergerak di sektor ini.

- Hubungan interpersonal antara Koperasi dan Anggota lebih kuat.

\subsubsection{Baitul Maal Wa Tamwil (BMT) :}

Baitul Maal Wa Tamwil (BMT), dalam bahasa Indonesia sering disebut dengan istilah Balai Mandiri Terpadu (BMT) merupakan salah satu lembaga pendanaan alternatif yang beroperasi di tengah masyarakat akar rumput. Pinbuk (1995) menyatakan bahwa BMT merupakan lembaga ekonomi rakyat kecil yang berupaya mengembangkan usaha-usaha produktif dan investasi dalam meningkatkan kegiatan ekonomi pengusaha kecil dan berdasarkan prinsip syariah dn koperasi.

BMT memiliki dua fungsi yaitu : Pertama, Baitul Maal menjalankan fungsi untuk memberi santunan kepada kaum miskin dengan menyalurkan dana ZIS (Zakat, Infaq, Shodaqoh) kepada yang berhak; Kedua, Baitul Taamwil menjalankan fungsi menghimpun simpanan dan membeayai kegiatan ekonomi rakyat dengan menggunakan Sistem Syariah.

Sistem bagi hasil adalah pola pembiayaan keuntungan maupun kerugianantara BMT dengan anggota penyimpan berdasarkan perhitungan yang disepakati bersama. Untuk menunjang permodalan, BMT membuka kesempatan untuk mendapatkan sumber permodalan yang berasal dari zakat, infaq, dan shodaqoh dari orang-orang tersebut.

Pola Tabungan dan Pembiayaan :

\section{Tabungan}

Tabungan atau simpanan dapat diartikan sebagai titipan murni dari orang atau badan usaha kepada pihak BMT. Jenisjenis tabungan/simpanan adalah sebagai berikut: (1). Tabungan persiapan qurban; (2). Tabungan pendidikan; (3). Tabungan persiapan untuk nikah; (4). Tabungan persiapan untuk melahirkan; (5). Tabungan naik haji/umroh; (6). Simpanan berjangka/deposito; (7). Simpanan khusus untuk kelahiran; (8). Simpanan sukarela; (9). Simpanan hari tua; (10). Simpanan aqiqoh.

\section{Pola Pembiayaan}

Pola pembiayaan terdiri dari bagi hasil dan jual beli dengan mark up

(1). Bagi Hasil.

Bagi hasil dilakukan antara BMT dengan pengelola dana dan antara BMT dengan penyedia dana (penyimpan/penabung). Bagi hasil ini dibedakan atas:

- Musyarakah, adalah suatu perkongsian antara dua pihak atau lebih dalam suatu proyek dimana masing-masing pihak berhak atas segala keuntungan dan bertanggung jawab atas segala kerugian yang terjadi sesuai dengan penyertaannya masing-masing.

- Mudharabah, adalah perkongsian antara dua pihak dimana pihak pertama (shahib al amal) menyediakan dana dan pihak kedua (mudharib) bertanggung jawab atas pengelolaan usaha. Keuntungan dibagikan sesuai dengan rasio laba yang telah disepakati bersama terlebih dahulu di depan. Manakala rugi, shahib al amal akan kehilangan sebagian imbalan dari kerja keras dan manajerial skill selama proyek berlangsung.

- Murabahah, adalah pola jual beli dengan membayar tangguh, sekali bayar.

- Muzaraah, adalah dengan memberikan 1 kepada si penggarap untuk ditanami dan dipelihara dengan imbalan bagian tertentu (prosentase) dari hasil panen. 
- Wusaqot, adalah bentuk yang lebih sederhana dari muzaraah dimana si penggarapnya bertanggung jawab atas penyiraman dan pemeliharaan. Sebagai imbalan si penggarap berhak atas rasio tertentu dari hasil panen.

(2). Jual Beli dengan Mark Up (keuntungan)

Jual beli dengan mark up merupakan tata cara jual beli yang dalam pelaksanaannya, BMT mengangkat nasabah sebagai agen (yang diberi kuasa) melakukan pembelian barang atas nama BMT, kemudian BMT bertindak sebagai penjual kepada nasabah dengan harga sejumlah harga beli tambah keuntungan bagi BMT atau sering disebut margin/mark up. Keuntungan yang diperoleh BMT akan dibagi kepada penyedia dan penyimpan dana. Jenis-jenisnya adalah:

- Bai Bitsaman Ajil (BBA), adalah proses jual beli dimana pembayaran dilakukan secara lebih dahulu dan penyerahan barang dilakukan kemudian.

- Bai As Salam, proses jual beli dimana pembayaran dilakukan terlebih dahulu dan penyerahan barang dilakukan kemudian.

- Al Istishna, adalah kontrak order yang ditandatangani bersamaan antara pemesan dengan produsen untuk pembuatan jenis barang tertentu.

- Ijarah atau Sewa, adalah dengan memberi penyewa untuk mengambil pemanfaatan dari sarana barang sewaan untuk jangka waktu tertentu dengan imbalan yang besarnya telah disepakati bersama.

- Bai Ut Takjiri, adakah suatu kontrak sewa yang diakhiri dengan penjualan. Dalam kontrak ini pembayaran sewa telah diperhitungkan sedemikian rupa sehingga padanya merupakan pembelian terhadap barang secara berangsur.

- Musyarakah Mustanaqisah, adalah kombinasi antara musyawarah dengan ijarah (perkongsian dengan sewa). Dalam kontrak ini kedua belah pihak yang berkongsi menyertakan modalnya masingmasing.

(3). Pembiayaan Non Profit

Sistem ini disebut juga pembiayaan kebajikan. Sistem ini lebih bersifat sosial dan tidak profit oriented. Sumber dan pembiayaan ini tidak membutuhkan biaya, tidak seperti bentuk-bentuk pembiayaan lainnya.

Pembentukan BMT :

Tujuan pembentukan BMT adalah untuk memperbanyak jumlah BMT sedangkan tujuan BMT itu sendiri adalah untuk : 1) memajukan kesejahteraan anggota dan masyarakat umum, 2) meningkatkan kekuatan dan posisi tawar pengusaha kecil dengan pelaku lain. Proses pembentukan BMT adalah sebagai berikut: Pertama, para pendiri minimum 20 orang. Para pendiri menghubungi PINBUK setempat untuk mengurus perijinan pendiriannya. Kedua, mendaftarkan calon pengelola untuk mengikuti pelatihan singkat dan magang. Ketiga, mempersiapkan modal awal sebesar Rp. 5juta di pedesaan dan Rp.10juta di perkotaan. Keempat, jika bermaksud menjadi koperasi, BMT dapat segera mengajukan permohonan badan hukum koperasi.

Hal-hal yang perlu diperhatikan dalam pembentukan BMT adalah:

1. Motivator (penggerak), memiliki peranan yang sangat signifikan terhadap sukses awal pendirian BMT. Penggerak ini berasal dari masyarakat setempat yang atas inisiatif sendiri atau inisiatif PINBUK dan pihak lain berminat membentuk BMT.

2. Pendekatan kepada tokoh kunci yang dapat terdiri dari pimpinan formal, pimpinan informal, usahawan, hartawan, dan dermawan. Para tokoh ini diharapkan bersedia menjadi Panitia Pembentukan BMT.

3. Pendekatan kepada para calon pendiri. Pendiri minimal 20 orang yang terdiri dari tokoh-tokoh yang mewakili berbagai kalangan masyarakat seperti pimpinan formal, agama, adat, pengusaha dan masyarakat banyak. Badan pendiri mengadakan rapat dan 
menetapkan Anggaran Dasar dan Anggaran Rumah Tangga BMT serta memilih pengurus yang terdiri dari $3-5$ orang.

4. Pengurus mengadakan seleksi pengelola yang jumlahnya minimal 3 orang yang terdiri manajer, bagian pembiayaan, bagian administrasi/keuangan dan bagianbagian lain yang dibutuhkan

5. Para pengelola yang ditunjuk segera memasyarakatkan BMT dan mencari anggota dan BMT mulai beroperasi.

6. Antara pengurus dan pengelola tidak mempunyai hubungan kekeluargaan.

7. Organisasi yang dapat membentuk BMT antara lain seluruh anggota masyarakat, kelompok-kelompok masyarakat, organisasi sosial, organisasi profesi, LSM, proyek-proyek pemberdayaan masyarakat

8. Kelompok yang dapat dikembangkan menjadi BMT antara lain: arisan, simpan pinjam, pengajian, tani, usaha ekonomi produktif dan lain-lain.

Pembiakan BMT :

BMT yang sudah mapan dan mempunyai pengelola yang terampil diharapkan dapat membentuk BMT baru di luar wilayah kerjanya. Langkah-langkah membentuk BMT adalah :

1. BMT yang sudah mapan sebagai BMT induk menempatkan seorang atau lebih pengelola yang terampil sebagai manajer BMT di wilayah kerja baru,

2. BMT induk memfasilitasi pembentukan BMT baru dan menyediakan sarana dan prasarana,

3. Pengelola BMT baru dibawah bimbingan BMT induk menyosialisasikan BMT pada masyarakat sekitar dan mulai beroperasi,

Pengelola BMT baru memperkuat BMT-nya dengan merekrut pendiri, membentuk pengurus dan menghimpun modal awal dari masyarakat sekitar. BMT induk bisa melepas BMT baru apabila BMT baru sudah kuat dan mandiri.

\section{PEMBAHASAN}

Sektor UKM diharapkan menjadi basis perekonomian dan dapat menggantikan peran pengusaha besar. Sejak krisis moneter yang diawali tahun 1997 hampir 80\% usaha besar mengalami kebangkrutan dan melakukan PHK missal terhadap karyawannya. Berbeda dengan UKM yang tetap bertahan di dalam krisis dengan segala keterbatasannya. UKM dianggap sektor usaha yang tidak cengeng dna tahan banting. Sehubungan dengan gambaran tersebut diatas tidak berlebihan apabila kita belajar dar jepang. Sejak reformasi sisten keuangannya pada tahun 1958, kekuatan eknomi jepang ditopang oleh UKM. Tetapi, sebagaimana biasa, apabila respons terhadap gagasan muncul dari birokrasi, rasa pesimisme merrebak dikalangan masyarakat. Kekwatiran utama adalah bahwa gagasan dan instrument kebijakan itu terpelintir oleh kepentingan ekonomi dan afiliasi politik sesaat dan memanfaatkan oleh petualang-petualang bisnis dan politik yang berada di lingkaran kekuasaan.

Masyarakat luas sebenarnya sangat paham bahwa strategi pengembangan UKM dan ekonomi rakyat secara umum tetap harus berbasis pada dua pilar utama yaitu : 1 . Tegaknya system dan mekanisme pasar yang sehat, 2. Berfungsinya aransemen kelembagaan atau regulasi pemerataan ekonomi yang efektif, namun untuk menegakkan dua pilar utama tersebut sering terjebak pad apilihan kebijakan dan strategi pemihakan yang skeptic dan cenderung mementingkan hasil akhir tersebut. Pemberlakuan UU no. 5/1999 tentang larangan praktik monopoli dan persaingan sehat juga belum menunjukkan hasil yang menggembirakan.

Basis UKM sendiri dan ekonomi rakyat secara umum ternyata sangat lemah dalam visi, sikap wirausaha dan manajemen bisnis yang paling mendasar, walaupun sering diklaim cukup dan bertahan dalam menghadapi krisis ekonomi yang masih belum dapat teratasi sampai sekarang. Hal tersebut didukung oleh laporan Biro Pusat Statistik (1999) dan Bank Indonesia (2000) yang menyebutkan pada masa tersebut UKM di Kota ternate justru meningkatkan kontribusinya terhadap PDB yaitu 56,72\% dari total PDB (BPS, 2004). Tetapi meskipun menunjukkan perbaikan, eksistensi usaha kecil diakui masih belum bisa terlepas dari beberapa permasalahan klasik yang menyertainya. Terutama masalah akses modal dan kesempatan mendapatkan peluang usaha, disamping masalah produksi, pemasaran, jaringan kerja dan teknologi.

\subsection{Potensi UKM di Kota Ternate}

Berdasarkan penelitian yang dilakukan oleh Dinas Koperasi dan Usaha Kecil Menengah 
Kota Ternate dengan Badan Pusat Statistik Propinsi Maluku Utara 234 usaha mikro atau merupakan 89,99\% dari keseluruhan jumlah kelompok usaha yang ada.penyebaran kelompok usaha kecil ini masih didominasi oleh sektor pertanian

Sampai dengan tahun 2009, jumlah tenaga kerja yang terserap dalam usaha kecil dari berbagai sektor ekonomi di Kota Ternate berjumlah 4.467 tenaga kerja atau $84,60 \%$ dari total penyerapan tenaga kerja yang ada di Maluku Utara. Hal ini menunjukkan bahwa tingkat penyerapan tenaga kerja usaha kecil di Kota Ternate adalah cukup besar adalah terbesar jika dibandingkan dengan tingkat penyerapan tenaga kerja pada usaha non usaha besar dan menengah.

Di dalam implementasinya sendiri lebih ke strategi/program permodalan yaitu memberikan modal bagi usaha kecil dan menengah dengan kreteria pinjaman dari 5 juta-25 juta dan untuk pinjaman lebih dari itu maka pihak dari Dinas Koperasi dan UKM mengarahkannya ke pihak Perbankan. namun program yang belum terlaksana untuk lebih memajukan UKM di Kota Ternate adalah belum terwujudnya UKM trade center yang nantinya dipakai sebagai tempat pameran dan pemasaran dari hasil-hasil UKM itu sendiri.

Data-data ini jelas menunjukkan betapa besarnya potensi UKM yang masih dapat dikembangkan, baik dalam hal produktivitas maupun daya saingnya sebagai institusi publik, PEMDA Kota Ternate memang sebaiknya hanya bertindak sebagai wasit yang adil dengan menciptakan lingkungan yang mendukung pengembangan UKM. Apakah PEMDA Kota Ternate cukup mampu menciptakan lingkungan yang konduktif bagi pengembangan UKM dan atau keterpihakan terhadap sektor itu sekedar retorika. Waktu yang akan membuktikan.

Salah satu usaha yang telah dilakukan PEMDA Kota Ternate pad atahun 2009 untuk menumbuh-kembangkan usah kecil dan sektor informal agar mampu menjadi usaha yang kokoh dan mandiri serta mampu meningkatkan pendapatan dan taraf hidup masyarakat melalui upaya koordinasi penyusunan kebijakan yang konduktif bagi pemberdayaan KUMKM, koordinasi perencanaan, pelaksanaan, pemantauan dan evaluasi program pemberdayaan KUMKM dan fasilitasi peningkata kapasitas masyarakat untuk pemberdayaan KUMKM , telah dikeluarkannya beberapa kebijakan yang terkait langsung dengan keberadaan dan kemampuan usaha kecil, yaitu :
1. Menciptakan iklim usaha yang konduktif bagi UMKM dan sebagai pendukung usaha mikro kecil dan menengah yang efisien secara ekonomi, sehat dalam persaingan dengan tujuan mempermudah, memperlrancar dan memperluas akses UMKM kepada sumberdaya produktif agar mampu memanfaatkan kesempatan yang terbuka dan potensi sumberdaya local serta menyesuaikan sakal usahanya sesuai dengan tuntutan efisiensi

2. Mengembangkan kewirausahaan dan keuggulan kompetitif UKM dan sebagai fasilitator pembiayaan koperasi, usaha mikro, kecil dan menengah dengan tujuan mengembangkan semangat kewirausahaan dan meningkatkan pendapatan masyrakat di sektor informal yang berskala usaha mikro terutama berstatus keluarga miskin dalam memperoleh pendapatan tetap.

3. Meningkatkan kualitas kelembagaan dan program pendukung koperasi agar koperasi mampu tumbuh dan berkembang secara sehat sesuai dengan jati dirinya menjadi wadah kepentingan bersama bagi anggotanya.

\subsection{Pengalaman di Negara Lain}

Jepang adalah Negara yang relatif berhasil dalam mengembangkan UKM sejak reformasi sistem keuangan. Untuk mengatasi siatuasi ini, pemerintah mendirikan lembaga penjamin kredit guna membantu para pengusaha kecil menengah dalam mengembangkan usahanya. Lembaga seperti ini di jepang namanya Credit Guarantee Corporation (CGC). Pendirian itu dimaksudkan untuk membantu UKM dalam memperoleh kredit dari Bank.

Malaysia. Di Malaysia perusahaan penjamin seperti CGC di Jepang dimiliki pemerintah dan Bank sentral, juga dari Bankbank komersil.dengan demikian prinsip kehatihatian dala menilai kredit sangat diutamakan

Pengalaman di Indonesia. Dewasa ini di Indonesia terdapat du BUMN lembaga penjaminan yaitu PT. Askrindo dan Perum PKK. PT. Askrindo memberikan jaminan kredit kepada bank untuk UKM, sedangkan Perum PKK untuk koperasi. Hal inilah yang memungkinkan bankbank kredit karena kredit-kredit macet ditanggung oleh PT. Askrindo. Hal ini pula yang menyebabkan banyak UKM mengalami kemacetan sehingga belum Nampak perkembangannya hingga sekarang. 


\subsection{Bimbingan Manajemen}

Beberapa persoalan yang tetap menghantui gerakan UKM selama ini adalah lemahnya gerakan ini di dalam mengantisipasi penggunaan teknologi yang kompetitif, kelemahan di dalam mengembangka jaringan pasar (perdagangan) termasuk penetrasi pasar, kesulitan di dalam mendapatkan modal kerja dan juga tidak adanya manajemen yang professional untuk mengelola bisnis yang bersangkutan.

Mengelola usaha kecil memerlukan ketrampilam yang berbeda dengan manajemen perusahaan. Untuk itu perlu bimbingan manajemen serta berbagai pelatihan yang berkesinambungan. Di Amerika Serikat ada organisasi yang membantu perkembangan usaha kecil dengan singkatan Score/Special Corps of Retired Executives atau Korps khusus dari Eksklusif yang telah pensiun.

Kelompok ini merupakan relawan yang terdiri dari pensiunan eksklusif baik dari pemerintah maupun swasta yang bertujuan membantu manajemen usaha kecil. Secara berkala UKM diberi pengarahan sehingga mutu SDM mereka secara bertahap meningkat. Tantangan berat uyang harus dihadapi di dalam mengembangkan UKM di Indonesia, terutama bagaimana mengubah paradigm para pengambil keputusan.

Di samping itu, tantangan yang tidak kalah besarnya adalah mensosialisasikan UKM dikalangan masyarakat luas bahwa golongan usaha ini merupakan lahan kerja yang menjanjikan, asal ditekuni dengan ekstra keras dan belajar terus menerus.

\section{PENUTUP}

Ubah Paradigma. Dari uraian diatas maka dapat disimpulkan untuk mewujudkan kiprah UKM di dunia bisnis, PEMDA Kota Ternate harus berupaya merubah paradigm yang selama ini sudah tertanam dalam sendi-sendi kehidupan UK dan ikut terjun secara langsung dalam system perdagangannya. Paradigm yang ada sekarang ini adalah Static Approach yaitu pendekatan berdasarkan input-proses-output, dimana hal tersebut akan menimbulkan kesulitan mencari pasar. Berbeda dengan Dynamic Approach yang berdasarkan pada output-proses-input.

Untuk mewujudkan itu antara lain :

1. UKM sebenarnya bisa menggunakan perangkat dan sarana yang sudah ada, yaitu berupa jaringan masyarakat pos ekonomi rakyat (jaringan PER) untuk mendampingi rakyat agar mereka mendapatkan akses informasi pasar, perkreditan, teknologi, dukungan konsultan usaha yang relevan bagi daerah

2. PEMDA Kota Ternate dapat meningkatkan kewirausahaan UKM yang identik dengan profesionalisme dan kreatifitas. Pemerintah dapat berfungsi sebagzai markerter dari UKM potensial atau berfungsi seperti jaringan PER

3. Perlu dibuat aturan yang jelas soal pemberian kredit, misalnya kredit dapat turun dan hanya dalam jangka pendek (1- 3 Bulan), itupun juga UKM tersebut menunjukkan kemajuan yang berarti. Pembayaran dilakukan setiap kali pesanan dilunasi, begitu seterusnya untuk order-order selanjutnya. Bila seluruh persyaratan terpenuhi segera dibantu pencairan biayanya, jangan terlalu lama dan bertele-tele. Jadi metode ini berprinsip pada untuk menghindari kesalahan yang terjadi sebelumnya yaitu dibiaya baru cari pasar, tetapi dengan metode ini cari pasar dulu baru dibiayai.

4. UKM dianggap sebagai partner dengan prinsip win-win solution antara pemeritah/ penjamin dan UKM

5. Diperlukan pelatihan yang bertujuan untuk mengubah pola piker/paradigm sebeagai seorang wirausaha agar UKM menjadi kuat, tidak manja, kreatif, inisiatif dan produktif, misal dengan pelatihan perubahan paradigm usaha, pentingnya kepuasan pelanggan, meningkatkan kreatifitas, inisiatif dan proaktif dalam usaha.

6. Menghilangkan kesan bahwa UKM hanya untuk yang berpendidikan rendah

7. Memberdayakan peran pemerintah daerah untuk meningkatkatkan UKM dengan langkah sebagai berikut :

a. Pilih UKM yang berpotensi di masingmasing daerah.

b. Mencari pasar untuk produk tersebut. Dapat melalui internet, pameran dan membentuk pusat perdagangan UKM (UKM trade center).

c. Bila ada pesanan dan sudah pasti, Maka UKM dapat dibantu oleh bank penjamin dengan surat pesanan.

d. Diperlukan tenaga pendamping yang bertugas untuk mempersiapkan ; UKM siap mandiri, UKM berbasis kualitas, UKM siap melakukan perbaikkan terus menerus. 


\section{DAFTAR PUSTAKA}

Bank Indonesia; “ Sistem Informasi Base Line Survey", hasil penelitian LP3E Fakultas Ekonomi Unpad, 2000.

Biro Pusat Statistik; " Statistik dalam angka" 2004

Tulus Tambunan : "Peranan UKM bagi Perekonomian Indonesia". Majalah Usahawan no.07 tahun 2002.

Vita Sarasi; “ Strategi pengembangan Bisnis berbasis kualitas produk pada UKM di Jawa Barat", Majalah Usahawan no.04 tahun 2002.

Pemerintah Daerah Kota Ternate Dinas Koperasi dan UKM; “ Laporan Rencana Kerja Dinas Koperasi dan UKM tahun 2009”, Tahun 2009. 